Feminist Fairy Tales for Black and American Indian Girls: A Working-Class

Vision

\author{
France Winddance Twine
}

Signs, Vol. 25, No. 4, Feminisms at a Millennium. (Summer, 2000), pp. 1227-1230.

Stable URL:

http://links.jstor.org/sici?sici=0097-9740\%28200022\%2925\%3A4\%3C1227\%3AFFTFBA\%3E2.0.CO\%3B2-J

Signs is currently published by The University of Chicago Press.

Your use of the JSTOR archive indicates your acceptance of JSTOR's Terms and Conditions of Use, available at http://www.jstor.org/about/terms.html. JSTOR's Terms and Conditions of Use provides, in part, that unless you have obtained prior permission, you may not download an entire issue of a journal or multiple copies of articles, and you may use content in the JSTOR archive only for your personal, non-commercial use.

Please contact the publisher regarding any further use of this work. Publisher contact information may be obtained at http://www.jstor.org/journals/ucpress.html.

Each copy of any part of a JSTOR transmission must contain the same copyright notice that appears on the screen or printed page of such transmission.

The JSTOR Archive is a trusted digital repository providing for long-term preservation and access to leading academic journals and scholarly literature from around the world. The Archive is supported by libraries, scholarly societies, publishers, and foundations. It is an initiative of JSTOR, a not-for-profit organization with a mission to help the scholarly community take advantage of advances in technology. For more information regarding JSTOR, please contact support@jstor.org. 


\section{Feminist Fairy Tales for Black and American Indian Girls: A Working-Class Vision}

n 1998 I was invited to participate in a workshop, "Feminism's Race Question," organized by feminist historians Ellen DuBois and Brenda Stevenson at UCLA. I left this conference revitalized and affirmed after listening to sessions that included Rosalyn Terborg-Penn, Evelynn Hammonds, Tessie Liu, Michael Awkward, and Eric Avila, among others. It was the first time that I had participated in panels that included black and Chicano male feminists from working-class origins along with established middle-class feminists. This workshop was the first I had attended that approached what I imagined a utopic feminist space/project to be: one that included women and men of color, working-class scholars, gay, lesbian, and queer scholars, as well as scholars trained in different disciplines and of different generations all engaged in dialogue.

What I envision two decades from now is working-class American Indian and U.S. black children claiming feminisms to empower themselves. I desire for the next generation what I was exposed to as a working-class girl living under American apartheid - a feminism that empowered me. I would like my experience of inclusion in feminist antiracist projects extended to future generations of working-class U.S. black and American Indian children who do not possess the cultural or financial capital to access a university education without a social justice movement. I want them to learn that feminism(s) can work for them. Is this "fairy tale" possible today in communities that differ from the segregated, working-class, and Catholic world in which I learned to claim feminism in Chicago two decades ago?

My journey to a feminist antiracist identity may be interpreted by some as a black feminist fairy tale, but it was a real product of the civil rights and women's movements. As a black girl (with an American Indian father) attending Catholic schools, I was taught by a series of feminists - mainly Irish Catholic nuns struggling to chart their own paths to antiracism. I

This essay and the previous one, by Karen Brodkin, come from conversations between the two authors across race and generation.

[Signs: Journal of Women in Culture and Society 2000, vol. 25, no. 4]

(C) 2000 by The University of Chicago. All rights reserved. 0097-9740/2000/2504-0042\$02.00 
learned in contradictory spaces that feminism belonged to me. I have no personal memories of a monolithic middle-class feminism not attached to an antiracist agenda, and it was not until the early 1980s, as a member of a feminist writers group (consisting mainly of Jewish feminist poets), that I read about the history of U.S. feminism and learned of various forms of exclusion and racism as practiced by white feminists. But I read this as past history because I had grown up with feminist antiracists of all ethnic backgrounds in my life. My earliest memories are of the civil rights and women's movements, and although I was too young to participate actively, I was taught that these social justice movements gave me access to a university education.

I had neither U.S. black feminist nor American Indian feminist mentors in the two departments (anthropology and sociology) in which I trained as a doctoral student. I entered the graduate program in anthropology at the University of California, Berkeley, in 1989 and was surprised to find no students of working-class origin, no U.S. blacks, and no American Indians in my cohort. Moreover, I was one of the few students who lacked a pedigree of academic parents or grandparents. This was a radical departure from my experience as an undergraduate at Northwestern University, a private institution that had a U.S. black student population of 12 percent and a significant number of working-class students at that time. While I encountered no working-class feminists among my peers in anthropology at Berkeley, I was mentored by several white feminist scholars, including Kristin Luker and Margaret Conkey, whose support (along with that of several black male scholars) prevented me from dropping out in response to the ongoing racism and elitism that prevailed.

In 1994, when I considered applying for academic positions as a U.S. black feminist trained in anthropology, I decided that the ideal place to synthesize my feminist and antiracist commitments was in a women studies department. I was thrilled when I was offered a women studies position, and I began my first lecture to two hundred students with these words: "I am here today because of the civil rights movement and the women's movement, and many of you are here because of these same movements." I then asked them to close their eyes and imagine a prefeminist world that lacked women faculty, feminist journals, feminist books, feminist publishers, and women graduate students.

While I have had several white feminist colleagues of working-class origins in the departments in which I have taught, there has been a continued absence of working-class U.S. black and American Indian faculty. The "diversity" criteria employed by some of my academic colleagues often assumes monolithic "white" and "women of color" categories that are not 
inflected by class. The absence of sustained reflection on the complex intersections of racism and class inequality - and their particular impact on U.S. blacks and brown-skinned American Indians who possess neither white skin privilege nor class privilege-has consequences for the future of women studies and gender studies departments. I am concerned about the lack of a sustained discussion of the exclusion from the tenured ranks in many women studies programs of U.S. working-class women (of all racial and ethnic backgrounds), particularly those who lack prestigious credentials from Ivy League or Ivy League-equivalent schools. I have witnessed patterns of recruitment and hiring that fail to consider how the valorization of scholars who possess class and cultural privilege (as measured by the "quality" of their degrees and letters) undermines the egalitarian ideals that women studies claims as a value. Consider the essays in Working-Class Women in the Academy, edited by Michelle M. Tokarczyk and Elizabeth Fay (1993). This volume includes essays by white working-class women struggling with pressures to devalue their cultural training, cultural style, and nonacademic lineage, which raises the question, Is it enough to simply consider hiring women of working-class origins and culture? The answer is No.

Feminist scholars must challenge the aristocratic leanings of institutional reward structures external to their departments that exclude nonelites. For example, scholars who possess certain "lineages," which include prestigious degrees, postdoctoral fellowships, and letters from "brandname" mentors, are typically assumed to be superior to scholars who are resource-deprived, their actual scholarly production notwithstanding. I have been privy to conversations in which feminist scholars who had produced work that I consider equal if not "superior" in terms of both quantity and quality were judged less qualified. Scholars with less prestigious degrees often have to overproduce to compensate for their poor lineage, but this situation is rarely acknowledged openly. In his analysis of the "habitus" of the academy, Paul Rabinow (1991) provides an example of how senior faculty assess the "character" of job candidates through their table manners. He argues, "The extent to which this art of symbolic navigation is a product of class and status socialization is revealed and highlighted by the entry of newer minorities into the arena, who, while mastering in diverse ways the codes of the academic world, reveal ... how habitual the 'docility' in its strict sense is. ... It is dangerous for the candidate or her supporters to point out these class- and status-based prejudgements to the old boys, who, proclaiming their perfect neutrality, will almost never engage on this ground" (69). Rabinow's analysis of the criteria used to exclude candidates whose bodily practices fail to conform to middle-class 
ways of comportment can also be applied to women of working-class origin attempting to secure positions in women studies departments.

In the 1980s the Reagan administration initiated a legislative assault on working-class students seeking higher education. Grants and low-interest loans of the sort that I received were eliminated. Today, working-class students have much less access to government-sponsored financial support for a university education than I did two decades ago. As affirmative action and poverty continue to be criminalized, academic feminists struggle to sustain a viable feminist antiracist project that is accountable to and includes non-elite women. Implementing diversification in ways that benefit primarily the most privileged women threatens to replicate structural inequalities while also reproducing impoverished university communities. Excluding scholars who lack prestigious pedigrees contributes to the political isolation of women studies programs in working-class communities. If women studies programs and departments are perceived to function as exclusive clubs that fail to actively recruit and support working-class women, they risk lacking political and moral credibility in working-class communities. Feminists have been central in creating more egalitarian spaces in the past, and we must continue the struggle to build antiracist and anti-elitist spaces of belonging.

Department of Sociology

University of California, Santa Barbara

Henry M. Jackson School of International Studies

University of Washington

\section{References}

Rabinow, Paul. 1991. "For Hire: Resolutely Late Modern." In Recapturing Anthropology: Working in the Present, ed. Richard Gabriel Fox, 59-72. Santa Fe, N.M.: School of American Research Press.

Tokarczyk, Michelle M., and Elizabeth Fav. 1993. Working-Class Women in the Academy: Laborers in the Knowledge Factory. Amherst: University of Massachusetts Press. 